\title{
THE ANALYSIS OF FIGURATIVE LANGUAGE USED IN THE LYRIC OF AWAKEN BY MAHER ZAIN
}

\author{
Taufik Ismail $^{1}$, Syifa Nuraeni ${ }^{2}$, Evie Kareviati ${ }^{3}$ \\ ${ }^{1}$ IKIP Siliwangi \\ ${ }^{2}$ IKIP Siliwangi \\ ${ }^{3}$ IKIP Siliwangi \\ ${ }^{1}$ taufikopikdede@gmail.com, ${ }^{2}$ nuraenisyifa.95@gmail.com, ${ }^{3}$ akhmadjaelani91@yahoo.co.id
}

\begin{abstract}
Figurative language is a part of semantic. This research analyzed the figurative language used in the lyric of Awaken by Maher Zain. The aims of this research are to figure out the figurative languages used in the lyric of Awaken and to analyze the contextual meaning of figurative language used in that song lyric. It is expected the result of this research will be useful for the reader especially in describing what figurative language is and what kinds of figurative language are. The design of this research is descriptive qualitative research. The lyrics of song is got from kapanlagi.com entitle Awaken. The result found that there are some kinds of figurative language used in Maher Zain's song entitle Awaken, such as hyperbole, rhetoric, repetition and personification. The contextual meaning of each figurative language is also clarified. The conclusion of this research is there are some kinds of figurative language use by Maher Zain in his song entitle Awaken.
\end{abstract}

Keywords: Figurative Language, Song Lyric, Types Of Figurative Language

\section{INTRODUCTION}

Language is system of conventional spoken or written symbols used by people for communicating with each other. People need language to communicate, to interact and to get information from other people. In this time, people can communicate with other through the song. It could deliver his voice to many people, there for people can understand his feelings.. According to Harmer (2007) as cited in Hariyanto (2017) language is used widely for communication between people who do not share the same first or even second language. It means that language can be a primary necessity in human life. It has a big role for every people in making good relationship with others. Language is a means of communications. Language has central role on intellectual development, social, and emotional students to supported success student and learn all of lessons, Parmawati (2018). Through language, people can express their ideas, thought, and feelings.

Listening song is fun activity, but the listeners could not get pleasure if they do not understand the figurative language that commonly found in song. Figurative language is commonly applied in literary works. One of the literary works is song. According to Shen (2009)as cited in Salwa 
\& Liskinasih (2016)Figurative language is language deflection to create certain and rhetorical effects or special meanings. Figurative language is a kind of language that starts from language employed the traditional literal ways of describing persons of object. It is usually immediately obvious weather a writer is figurative language. Repetition, hyperbole, simile, symbol, and forth were found to be the common figurative used by performing artist when composing his or her song, figurative language does not mean exactly what it says, but instead forces the reader to create an imaginative leap in order to comprehend an author's point.

Merriam-Webster's encyclopedia of Literature (1995) as cited in Coelho \& Alchemist (2016) states that figurative language or figures of speech can be classified into five categories, for example:

1) Figures of resemblance on relationship (e.g. simile, metaphor, kenning, conceit, parallelism, personification, metonymy, synecdoche, and euphemism).

2) Figures of emphasis or understatement (e.g. hyperbole, litotes, rhetoric, question, antithesis, climax, bathos, paradox, oxymoron, and irony).

3) Figures of sound (e.g. alliteration, repetition, anaphora, and onomatopoeia).

4) Verbal games and gymnastics (e.g. pun and anagram).

5) Errors (e.g. malapropism, periphrasis, and spoonerism).

Kennedy (1991) as cited in Aprisnindianningrum, Fardhani, Andayani(2015) classifies figurative language into eleven types. The types of figurative language would be explained which related to this research and it will be used in analyzing the findings, they are:

1) Metaphor is a statement that one thing is something else, that in literal sense, it is not. It does not use connective words such as like or as.

2) Simile is comparison of two things, indicate by some connective usually like, as, than or verb such as resembles.

3) Metonymy is the use of something closely related for the thing actually meant.

4) Synecdoche is use of a part of a thing to stand for the whole of it or vice versa.

5) Transferred epithet is consisted reference to explain a nature or typical characteristic from someone or something

6) Personification is a figure of speech in which a thing, an animal, or an abstract term is made by human.

7) Rhetoric is a figure of speech by question, which actually does not need to be answered because the answer of the question is already contained in the question. 
8) Hyperbole is a figurative language that emphasizes the point with a statement containing exaggeration.

9) Repetition is repetition tone, syllable, word or part of sentence which is considered important to give stress in a appropriate context.

10) Paradox occurs in a statement that at first strikes us as self-contradictory but that on reflection make some sense.

11) Paronomasia is an expression intended for humorous or rhetorical effect by exploiting different meanings of words.

There are some studies which have done by previous researchers. Hornby USA (1995) as cited in Setiawati \& Maryani (2018) can be defined song as a short rhyme or set of verses in music and aimed to be sung Her findings showed that there are figurative languages found in Adele's song lyric and described the types and contextual meaning of figurative language in the song. Perrine and Thomas (1983:81) as cited in Syafitri \& Marlinton (2018) stated that figurative language is a persuasive language. Due to interest in the research of figurative language, this research focused on figurative languages which are used mainly in the song lyric of Awaken from Maher Zain. Awaken is one of familiar song from Maher Zain. This song is one of favorite Islamic song. Based on the explanation above, the researcher will take a research entitle The Analysis of Figurative Language Used in the Lyric of Awake from Maher Zain.

Therefore, the present research attempted to address the following research questions:

1. What types of figurative language are used in Awaken by Maher Zain?

2. What are the contextual meanings of figurative language used in the song lyric of Awaken by Maher Zain?

\section{METHOD}

The method which is used in this research is descriptive qualitative analysis means to describe what actually happen to procedures about the method which are useful in research. Descriptive qualitative approach does not apply the detail arithmetic calculation or statistic contains sentence or description of the object (Moleong, 2011) as cited in Listiani (2015).

In this research, the researcher is the main instrument. The researcher directly observed the song lyric of Awaken by Maher Zain. The researcher analyzed the song lyric to figure out the figurative language used in that song and the meaning of that figurative language use. The researcher focused on analyzing the song lyric of Maher Zain entitled Awaken that used figurative language. The researcher took it from the website kapanlagi.com.

The data in this research is one of songs by Maher Zain entitle Awaken. The researcher adopted it because that song is familiar and getting interest to figure out the implicit meaning of that song. After taking the song lyric from internet source, the researcher started by reading the song 
lyric and listen to the song. Next the researcher attempted to figure out the word, phrase, and sentence which contain of figurative language and grasping the meaning of each figurative language use in that song. After that, the researcher created a note which is one of the figurative language. Finally the researcher classified the data into kinds of figurative language then analyzed it.

After finding the figurative language in the lyric, the first step in the analysis is identifying the types of figurative language such as metaphor, simile, hyperbole, idiom, personification, symbolism, synecdoche, repetition and forth. The next step is analyzing the meaning of each figurative language. And the last is making conclusion.

\section{RESULTS AND DISCUSSION}

\section{Results}

This part showed the result of the data analysis of the figurative language and the contextual meaning of each figurative language found in the lyric of Awaken by Maher Zain and the researcher analyzed it. It is conducted to figure out the figurative language use in that song. The figurative language use in that song can be seen in table 1 .

Table 1

\begin{tabular}{lll} 
No & Expression/Lyric & Figurative Language \\
\hline 1 & We change the desert into oasis & Hyperbole \\
\hline 2 & And we felt so very satisfied & Hyperbole \\
\hline 3 & We could not stop buying & Hyperbole \\
\hline 4 & Oh ... I'm walking with my head lowered in my shame & Hyperbole \\
& from & \\
& my place, I'm walking with my head lowered from my & \\
& race & Hyperbole \\
\hline 5 & Yes we felt so very satisfied & Hyperbole \\
\hline 6 & We bought and bought, Maybe all the fancy cars & Personification \\
\hline 7 & We felt our money gave us infinite power & \\
\hline 8 & Is Allah satisfied? Is Allah satisfied? Is Allah & Repetition \\
& satisfied? & \\
\hline 9 & $\begin{array}{l}\text { I'm walking with my with my head lowered in shame } \\
\text { from }\end{array}$ & Repetition \\
& $\begin{array}{l}\text { my place, I'm walking with my head lowered from my } \\
\text { race? }\end{array}$ &
\end{tabular}


10 We bought and bought

Repetition

11 Is He satisfied? Is Allah satisfied? Is Allah satisfied? Rhetoric and Repetition Is

Allah satisfied?

\section{Discussion}

The table shows that the classification of figurative language use in the Awaken song by Maher Zain. It told in which position the figurative language occur in that song. The figurative languages found are 6 hyperboles, 1 personification, 3 repetition and 1 rhetoric. They are used in that song as the messages of the text in song Awaken in order to create a beautiful meaning and creative literature so the listener will be interest to hear the song.

The analysis of contextual meaning of figurative language use in song lyric of Awaken by Maher Zain It is important to know the meaning of the figurative language use in a song. This season about the meaning of figurative language found in research question 1.

\section{Lyric 1}

"We change the desert into oasis"

The sentence is included in the hyperbole because the phrase has dramatic effects such as the word "desert" and "oasis", these words actually do not tell what happened. The used of this figure of speech is to show that the condition terrible, and on the word "oasis" the condition is excellent. In addition, the election of the words above is to make language good illuminate.

Lyric 2

"And we felt so very satisfied"

This sentence entered the category of hyperbole because it causes excessive effect. Actually the writer might say "and we felt very satisfied", but the writer added the word "so" to be "and we felt so very satisfied," to give the impression that he was contented.

\section{Lyric 3}

"We could not stop buying"

This sentence entered the category of hyperbole because this lyric song was used the words that produce very dramatic effect, such as "could not stop buying" which means always buy and buy nonstop

\section{Lyric 4}

"Oh ... I'm walking with my head lowered in my shame from my place, I'm walking with my head lowered from my race"

This sentence entered the category of hyperbole because this lyric song was used the words that produce very dramatic effect such as "walking with my head" These words actually do not tell what exactly happened. The composer wanted to say that he was bowed with embarrassment to the state of the facts. 
Lyric 5

"Yes we felt so very satisfied"

This sentence entered the category of hyperbole because this lyric song was used the words that produce very dramatic effect. Actually the author might say "and we felt very satisfied", but the author added the word "so" to "and we felt so very satisfied," to give the impression that he was very, very satisfied.

Lyric 6

"We bought and bought, Maybe all the fancy cars"

This sentence entered the category of hyperbole because this lyric song was used the words that produce very dramatic effect. The composer wants to convey if they buy all luxuries.

Lyric 7

"We felt our money gave us infinite power"

The sentence categorized into personification, because this lyric song assigning human characteristics to nonhuman object. Composer wants to say if their money will never run out

Lyric 8

"Is Allah satisfied? Is Allah satisfied? Is Allah satisfied?"

In addition to including from the category of Rhetoric, the sentence is also included in the category Repetition because the three sentences are repetitive. Composer wants to say that what we are looking for is willing Allah.

Lyric 9

"I'm walking with my with my head lowered in shame from

my place, I'm walking with my head lowered from my race?"

The sentence categorize into repetition, because the lyric is repeated.

Lyric 10

"We bought and bought"

The sentence categorize into repetition, because the lyric is repeated. Composers want to say that they always buy all the luxuries.

\section{Lyric 11}

"Is He satisfied? Is Allah satisfied? Is Allah satisfied? Is

Allah satisfied?" 
The sentence categorized into Rhetoric, because in fact the question does not require an answer. Composer wants to say if we have to correct ourselves. After that, the sentence categorize into repetition, because the lyric is repeated.

\section{CONCLUSION}

The research was conducted to analyze Maher Zain's song lyric entitle Awaken. Based on the results of the research, researchers found figurative language in the song lyrics. There are four figurative languages found, namely, hyperbole, personification, rhetoric and repetition. The dominant type of figurative language that found in this song lyric was hyperbole. The figurative language found in this song is almost all positive, describing happiness, religious and reminder. The song was made to make life stories more better especially Islamic life and clarify that religion side is upper than the other thing. A song analyzed cannot only be according to one word, but must be understood based on the context of the entire lyrics. Therefore, to know the meaning and understand a word from a song is needed to use figurative language so that it is easier to interpret the actual ideas and feelings of a song lyric.

\section{ACKNOWLEDGMENTS}

Alhamdulillahi robbil 'alamin, the researcher expressed his highest gratitude to Allah Subhanahu wa ta'ala for his blessings, love, opportunity, health, and mercy to finish this journal. We are also grateful to Ms. Evie Kareviati M,Pd, who has guided our journal patiently, thanks to colleagues who have also provided support. And the journal that we made is titled " The Analysis of Figurative Language Used in the Lyric of Awaken by Maher Zain " Submitted as a requirement for the thesis trial. English Language Education, IKIP Siliwangi Bandung.

\section{REFERENCES}

Analysis, A., Used, F. L., Coelho, P., \& Alchemist, T. (2016). An Analysis Of Figurative Languages Used. (2), 45-63.

Aprisnindianningrum, S., Fardhani, A. E., Andayani, M. A., Language, E., \& Program, E. (2015). Finding Meaning Of Figurative Language Use In Advertisements For Foreign Language Education. 1-3.

Hariyanto. (2017). The Analysis Of Figurative Language Used In The Lyric Of Firework By Katy Perry ( A Study Of Semantic ). Graduate Program, Lampung University, 10(1), 4660.

Listiani, H. (2015). An Analysis Of Figurative Language Found On The Song Lyric By Taylor Swift' $S$ “ Speak Now " Album By: Teacher Training And Education Faculty State Institute For Islamic Studies.

Parmawati, A. (2018). The Study Correlation Between Reading Habit And Pronunciation 
Ability At The Second Grade Students Of Ikip Siliwangi. Eltin Journal, Journal Of English Language Teaching In Indonesia, 6(1), 46-52.

Salwa, S., \& Liskinasih, A. (2016). The Use Of Songs In Increasing Students' Understanding Of Figurative Language. Ijee (Indonesian Journal Of English Education), 3(1), 75-88. Https://Doi.Org/10.15408/Ijee.V3i1.3443

Setiawati, W., \& Maryani. (2018). An Analysis Of Fgurative Language In Taylor Swift's Song Lyrics. Profesisonal Journal Of English Education, 01(03), 261-268.

Syafitri, D., \& Marlinton, M. (2018). An Analysis Of Figurative Language Used In Edgar Allan Poe's Poems. Linguistic, English Education And Art (Leea) Journal, 2(1), 43-59. Https://Doi.Org/10.31539/Leea.V2i1.453 